\title{
Online marketing lehetőségek és kihívások az autószerelök piacán
}

\author{
Kurucz Attila - Pete Dorottya - Keller Veronika \\ Széchenyi István Egyetem
}

\begin{abstract}
A TANULMÁNY CÉLJA
Jelen kutatás célja a szolgáltatószektorban működő hazai autószerelő és -javító vállalkozások online megjelenésének feltérképezése. Az autószereléssel kapcsolatos szavak keresési találatainak köszönhetően elérhető honlapok elemzése tartalom, design és felhasználói tapasztalat (UX) szempontjából. További cél a honlap létrejötte és a vizuális design közötti, az oldalak információtartalma és a hirdetett szavak száma közötti, valamint a weboldalak nyitó oldalának típusa és a hirdetés tárgya közötti összefüggések feltárása.
\end{abstract}

\begin{abstract}
ALKALMAZOTT MÓdSZERTAN
A gépjárműjavítással, szervízeléssel kapcsolatban 100 kulcsszót gyüjtöttünk össze és a Google Ads hirdetések hatására elért weboldalakat (88) kvalitatív szempontok - a link nyitóoldala, a hirdetés tárgya, reszponzívitás, sütik használata, design, tartalom, UX - szerint elemeztük. Majd kvantitatív tartalomelemzés segítségével ismertettük a kutatási eredményeket. A keresések (lekérdezések) módszerét standardizáltuk - lokalizációhoz, időszakokhoz és hálózathoz (ugyanaz az IP cím) kötöttük -, hogy az összevetés releváns maradjon.
\end{abstract}

\section{LEGFONTOSABB EREDMÉNYEK, ÚJDONSÁGOK}

A weboldalak 65\%-a minden szempontnak megfelelt, azaz egységes volt a színvilága, a vizuális elemeket jól alkalmazta, illetve megfelelő mennyiségü információt tartalmazott. Minél több információval van ellátva egy honlap, annál több kifejezésre van lehetősége a vállalatnak hirdetni. A Google algoritmusa figyelembe veszi a releváns tartalmakat, ami az organikus, és a fizetett elérések szempontjából is magasabb minőséget nyújt.

\section{GYAKORLATI JAVASLATOK}

A kutatás eredményei hasznosak lehetnek a KKV szektor számára, különösen a gépjármüszervízeléssel foglalkozó cégeknek. A hazai KKV szektornak érdemes figyelemmel kísérni az aktuális online marketing trendeket és a változó fogyasztói igényeket, elvárásokat, hiszen a jól átgondolt, arculati elemekhez illeszkedő, kellően informatív ugyanakkor kreatív elemekben bővelkedő honlap és a tudatos keresőmarketing tevékenység hozzájárul a versenyelőny megszerzéséhez.

Kulcsszavak: online marketing, Google Ads hirdetések, gépjármüszervíz

DOI: 10.15170/MM.2021.55.02.08 


\section{BEVEZETÉS INTRODUCTION}

2021 januárjában a világ internet felhasználóinak száma több mint 4,66 milliárd volt (a világ népességének 59,5\%-a), hazánkban pedig 8,01 millió fö, vagyis a lakosság $83 \%$-a, ami egy év alatt 4,8\%-os növekedést jelentett (Kemp 2021). Az online marketing térhódítása a hazai piacon is megfigyelhetö. Webes megjelenés nélkül egyetlen vállalkozás sem lehet sikeres. Habár ma már sok platform ad lehetőséget az üzleti szereplőknek, hogy népszerüsítsék magukat a piacon, mégis az online hirdetés legkorábbi megjelenése maga a weboldal volt, és máig ez a legnépszerúbb forma (Kumar et al, 2020). Ugyanakkor a közösségi terek erős versenytársnak számítanak. Az idő előrehaladtával és a technológiák fejlödésével számtalan online marketing eszköz jött létre és jön létre folyamatosan. Scott Brinker, neves marketing blogger 2011-ben összesen 150 marketing eszközt gyüjtött össze, ezt a kutatását mai napig évente megújítja. 2012-ben már 350-re bővült a listája, majd 2018-ban 6289-re, majd 2020ban közel 8000 darabot jegyzett. A fejlődés láthatóan nem állt meg, és hétről hétre születnek az újabb eszközök (chiefmartec.com). A Magyar Reklámszövetség összesített adatai alapján a 2020-as teljes médiatorta a 2019-es 245,08 milliárd forintról 240 milliárd forintra csökkent. A digitális reklám változatlanul a legerősebb piaci szereplő $(44,7 \%)$ az előző időszakhoz képest bekövetkezett növekedése a leginkább számottevő (MRSZ 2020). 2018-ban az Európai Unióban átlagosan a vállalkozások $77 \%$-a rendelkezett honlappal. A magyar vállalkozások kétharmada élt az internet adta lehetőségekkel, ezzel hazánk még mindig az uniós rangsor alsó harmadában helyezkedett el (KSH 2018). A KSH adatai értelmében 2020-ban a vállalkozások honlapján az alábbi szolgáltatások érhetők el: termék-és szolgáltatásinformációk (81,3\%), linkek és kapcsolatok a vállalkozás közösségi média profiljaihoz (38,3\%), online megrendelés $(27,8 \%)$, a termék testreszabásának lehetősége (14,5\%) (KSH 2020).

A honlap fontossága miatt esett érdeklődésünk középpontjába egy jellemzően nem vizsgált szektor webes megjelenésének elemzése. Tanulmányunk célja a KKV marketing mellett a webdesignnal és a keresőmarketinggel kapcsolatos szakirodalmi áttekintés, valamint adott szolgáltatási iparághoz tartozó kulcsszavas keresési módszer bemutatása. Továbbá az eredmények által talált honlapok empirikus elemzése tartalom, design és felhasználói tapasztalat (UX) szempontjából. A választott szektor a népszerü autóiparhoz kapcsolódik, de nem a gyártás, hanem az értékesítés utáni after sale szolgáltatásokat végző autószerelők, -javítók szegmense. 2017-ig az autoszektor.hu foglalkozott az Országos Autószerelők Egyesületének helyzetével, és több írást is megosztott föként a szakképzést érintő kérdésekben. 2013 és 2016 között a szektor jelentős átrendeződése volt jellemző. A vállalkozások száma 10000-et meghaladó számról 9434-re csökkent, mégis az árbevételek és a foglalkoztatotti létszámok növekedtek (autoszektor.hu).

\section{SZAKIRODALMI ÁTTEKINTÉS LITERATURE REVIEW}

A digitalizáció korában kiemelten fontos a KKV-k online jelenléte. Hazánkban a KKV-k online marketingtevékenységükkel egyszerre bizonyítják innovációs képességüket, és növelik marketing tevékenységük eredményességét (Gáti 2015). Ez a gondolati dilemma már megjelenik Romano és Ratnatunga (1995) korai munkájában, amikor is a kisvállalati marketinget igyekezett három kategóriába sorolni, úgymint „kultúra”, „stratégia”, és „taktika”. Miután sokat erősödött a marketing stratégiai irányzata méltán tekintik sokan kiindulásnak Carson (2001) fejlődéselméleti megközelítését, ahol négy fázisra osztja a KKV marketing lehetséges fejlődésútját (kezdetek, útkeresés, bütykölés, mestermunka). Ehhez képest Moller és Anttila (1987) egy mátrix-alapú marketing képességek keretrendszert javasoltak a skandináv termelő kisvállalkozások megfigyelésére hagyatkozva. A múltbeli helyzetértékelésből kiindulva átfogó munkát szerkesztett Nwankwo és Gbadamosi (2020), amelyben igyekeztek a jelen kor stratégiai kérdéseit (árazás, kapcsolatmarketing, globális piacok, kommunikáció, vállalkozói kompetenciák) összegezni és a jövőbeli trendeket feltérképezni. Úgy találták, hogy a digitalizáció és a robotizáció jelentősen megváltoztatja majd a kisvállalkozások marketingtevékenységét ezzel együtt a marketinges munkaköröket is.

A hazai irodalom szintén széles spektrumon tekint a KKV marketing kérdéskörére, hiszen több esetben a marketing erőforrás-elméleti megközelítését olvashatjuk, így az információ vagy éppen a tőke, mint erőforrás meghatározó szerepe jelenik meg (Sasvári 2012, Holló - Marselek 2017). Mások kiemelik a vállalkozó meghatározó szerepét a cég brandje és a piaci eredményessége szempontjából. Nem feltétlenül arra gondolunk, hogy ki az arca vagy éppen ki az ember a cég mögött, hanem hogy a döntések magasszintű koncentráltsága több esetben korlátként jelentkezik a KKV szektor sze- 
replőinél (Gáti - Csordás 2013). Ennek többnyire a tudáshiány, konkrétan az online marketing ismeretek hiánya jelent korlátot (Békési 2011). A KKV-k egy jelentős része még nincs jelen a weben, vagy ha jelen is van az nem elég kielégítő még saját maguk számára sem (Harsányi et al, 2020).

A hazai tudományos életben az új média és a digitális marketing jegyeinek (pl.: korosztályok, platformok, stratégiák, speciális iparágak) kutatása került a kutatók érdeklődésének középpontjába (Fehér 2019, Vincze 2019, Buvár 2018, Veszelszki 2019).

Az üzleti céljuk alapján többféle weboldalt különböztethetünk meg, ilyenek az általános bemutatkozó, az értékesítés-központú, a branding és egyéb, például ügyfélszolgálati oldalak, kampányoldalak, internetes szolgáltatásokhoz köthető adminisztrációs oldalak. Az általános bemutatkozó oldalak fő célja az információk közlése, másodlagos a design, azaz a megjelenés. A weboldalak esetében lényeges a használhatóság és a jó felhasználói felület (Bartha-Márkus 2016), valamint a ,keresőoptimalizálás, vagyis az oldal olyan módon történő kialakítása, amely könnyen megtalálhatóvá teszi azt a keresőkben" (Bányai 2011, 159). A weblapdesign nem egy müvészet, hanem a kommunikáció egy formája. Így a honlap elemzések módszertana és szempontrendszere is egyre több esetben válik a szakirodalom témájává. Harsányi et al. (2020) munkájukban a következő szempontrendszert határozták meg: 1) tartalom (benne interaktivitás); 2) felhasználói élmény (UX) (benne sebesség); 3) design; 4) kereső; 5) technológia (benne reszponzibilitás); 6) kötelező elemek. Kató és Keller (2019) a húsipari vállalatok weboldalainak elemzését szintén hat hasonló objektív és szubjektív szempont szerint végezték el: 1) User Experience (UX); 2) design elemek; 3) tartalom, 4) interaktivitás; 5) kreativitás; és 6) technológiai tényezők. A webdesign kutatások nemzetközi fókuszába újabban a márkák logóinak vizsgálata (Suarez-Carballo et al, 2020), az önkifejezést segítő blogok (Adami, 2018) design-jának elemzése, valamint az interkulturális megközelítések (Cermak, 2020) kerültek. Ez utóbbiak rávilágítottak, hogy az eltérő kultúrájú országok (Hofstede dimenziói alapján) más tartalmakat és webdesign funkciókat, UX elemeket alkalmaznak. Módszertani szempontból a tartalomelemzés, esettanulmány módszer kerültek alkalmazásra.

A weboldal kialakítása fontos, hiszen a különféle hirdetések érkezési oldalaként szolgálnak, így a virtuális piacon az üzlet helyszíne lesz. Ebből az aspektusból már nehezebb rangsort állítani a weboldalak jegyei között. Fontosabb kiemelni, hogy a megfelelő weboldalnak illeszkednie kell a cég marketing és egyéb üzleti stratégiájához (Kató - Keller 2019).

Keresőoptimalizálást az angol Search Engine Optimalisation (SEO) kifejezés rövidítéseként találjuk meg a hazai szakirodalomban is. Az online marketing egyik legrégibb, mégis talán legfontosabb eszközévé lett. A Google célja, hogy a felhasználók által megadott kulcsszavakra releváns tartalmakat biztosítson (Zhao 2004, Schmuck 2019). Ennek lényegében három feltétele van. Az egyik a weboldal technikai felépítése, a másik, hogy menynyire releváns a weboldalon található tartalom a megadott kulcsszóra, kifejezésre, valamint, hogy a forrás, vagyis a weboldal mennyire megbízható. A Google keresőmotorja is sokat változik, de alapvetően a megbízhatóságot a hivatkozások alapján méri. Az interneten a linkek weboldalakat kötnek össze, mégpedig úgy, hogy egyik weboldal hivatkozik a másikra. A keresőrobotok is így térképezik fel a webet, vagyis hivatkozásról hivatkozásra járnak. Ennek értelmében a Google azokat a weboldalakat fogja megbízhatónak tartani, amelyek másik megbízható oldalakról is hivatkozást kapnak. Mivel a keresőrobotok rangsorolják a honlapokat érdemes úgy elkészíteni őket, hogy az előbb felsorolt feltételeknek megfeleljenek. A keresőoptimalizálás során nem kell fizetni azért, hogy az oldal jobb helyet kapjon a találatok között. A megfelelö kulcsszavak kiválasztása és alkalmazása határozza meg a keresésoptimalizálás sikerességét. Dieguez és társai (2021) kiemelik, hogy a hatásos és jól menedzselt SEO stratégia ingyenes és vonzó weboldalt jelent hosszú távon. Minél többször fordul elő az adott szó az oldalon, annál nagyobb az esélye a jó találati helynek (Eszes 2011). A SEA (Search Engine Advertising), esetében, viszont fizetni kell azért, hogy az oldal jelenjen meg a hirdetések között. A SEO és a SEA alkotják együtt a SEM-et vagyis a Search Engine Marketing-et (webshark.hu). Barry és Charleton (2008) az ír KKV-k vizsgálata során úgy találták, hogy a leggyakrabban használt SEM módszer a címben vagy a leíró tag-ban szereplő kulcsszó, illetve a honlapon elhelyezett kulcsszavak és a kattintás alapú hirdetések. Aswani és társai (2017) a keresőmarketingben rejlő veszélyekre hívták fel a figyelmet, hiszen a nem megfelelö használat piaci és adatkockázatot jelent a kis-és középvállalatok számára. Újabb nemzetközi kutatások a tartalomelemzés segítségével vizsgálták a keresőszavak találati oldalit a legnagyobb keresőmotorkban egy-egy speciális iparághoz - egészségügy, össejtbank (Chavez et al, 2021), turizmus, szálláshely értékesítés (Kaewmanee et al, 2021) kapcsolódóan. 
A Google Ads az egyik legismertebb és legnagyobb keresőmotor és a hazai KKV-k legnépszerübb hirdetési eszköze (Bányai 2016). A Google Ads hirdetések lehetnek keresési-, vizuális-, videóés alkalmazáshirdetések. Ezeknek a legnagyobb előnye, hogy kizárólag az eredményekért kell fizetni (PPC - pay per click hirdetések). A Google nemrég olyan változásokat valósított meg az algoritmusában, melyek jobban koncentrálnak a tartalom minőségére és naprakészségére (https://www. searchenginejournal.com/). Ezért nem elég hangsúlyozni a KKV-k számára a tartalommarketing jelentőségét (Csordás - Gáti 2014).

\section{ANYAG ÉS MÓDSZER MATERIAL AND METHODO- LOGY}

A szakirodalmi áttekintés alapján megállapíthatjuk, hogy a kisvállalkozások online megjelenése valós marketingkutatási terület, amelyen belül érdemes fókuszáltan - kiemelt szektorokat - vizsgálni. Kutatásunk tárgyául - a bevezetőben tett indoklásunk okán - a gépjármüjavítással foglalkozó szolgáltató vállalkozások kerültek, erősítve azzal a ténynyel, hogy a szolgáltatások közül a kereskedelem és a gépjármủjavítás szerepe a legjelentősebb. A KKV szektoron belül a foglalkoztatotti létszám (21\%), az árbevétel (38\%), valamint a hozzáadott érték $(22 \%)$ alapján egyaránt e terület súlyaránya volt a legmagasabb (KSH 2018). Az online marketing szakirodalomban megjelenő weboldalakkal kapcsolatos elemzések kiemelik az oldalak kommunikációban és reklámban meghatározó szerepét és a felhasználói élmény fontosságát (Farell 2017).

Mindennek alapján az alábbi kutatási kérdéseket fogalmaztuk meg:

- Milyen Google Ads hirdetések jelennek meg az autószereléssel kapcsolatos szavak keresése során?

- Hogyan jellemezhetők ezek a weboldalak design, tartalom és UX szempontjából?

- Van-e összefüggés a honlap létrejötte és a vizuális design között?

- Van-e összefüggés az oldalak információtartalma és a hirdetett szavak száma között?

- Van-e összefüggés a weboldalak nyitó oldalának típusa és a hirdetés tárgya között?

A kutatási kérdések megválaszolásához empirikus kutatást végeztünk. A megfigyelés módszerén belül a tartalomelemzést választottuk és egy adat- bázist készítettünk, amit egy- (gyakorisági eloszlások) és többváltozós statisztikai módszerekkel (kereszttáblaelemzés és varianciaelemzés) elemeztünk az SPSS statisztikai program segítségével. Fontos megemlíteni, hogy nem netnográfiai (Csordás - Markos-Kujbus 2018) vizsgálatot végzünk, hanem az üzleti megjelenés marketing szemléletü elemzését tűztük ki célul. A szolgáltatási szektorban kimagasló, gépjárműjavítással foglalkozó vállalkozások SEM hirdetéseit vizsgáltuk a Google felületén. A lekérdezések megvalósításánál figyeltünk a Google algoritmusára. Egy olyan rutint követtünk, amelyet szeretnénk mintaként állítani a jövőbeli hasonló kutatásokhoz. Így figyeltünk a hirdetési paraméterezés lehetőségeire, a lekérdezés helyszínére (adott település), a lekérdezések futtatásának időszakára (munkanapokon munkaidőben), behatárolt időszakban (4 hétig) tekintettük a hirdetéseket, egy előre meghatározott, a szektorra jellemző keresőkulcsszó bázis alapján.

A SEM közül a Google Ads segítségével létrehozott hirdetéseket vizsgáltuk. A hirdetés lényege, hogy a felhasználók számára, akkor válik láthatóvá, amikor egy a vállalathoz kapcsolódó szóra keresnek rá, például: gépjármüszerelés vagy gumicsere. A hirdetőnek lehetősége van beállítani, hogy helyileg hol jelenjenek meg. Megadhatja a bolt bizonyos sugarát, teljes régiókat vagy országokat. Meghatározhatja a kívánt költségkeretet, melyet bármikor változtathat vagy szüneteltethet, viszont csak azért kell fizetniük, ha a felhasználó rákattint a hirdetett linkre, a megjelenésért nem. A fizetett keresési hirdetések a keresési találatok tetején helyezkednek el, illetve a legalján. Maximum egy keresés során hét darab fizetett hirdetés jelenik meg a többi organikus hirdetés között (https://ads.google.com/intl/hu_hu/ home/how-it-works/).

Ezeket a beállítási lehetőségeket figyelembe kellett vennünk a kutatás folyamata során, mivel más keresési eredményeket kapunk más-más városban, vagy időpontban. A kutatást Győrben végeztük, munkanapokon, reggel 8 és délután 4 óra között 2019 augusztusában. A kutatási időszak összesen négy hétig tartott. A kutatás során 100 szóra kerestünk rá, amelyek a gépjármüjavításhoz kapcsolódtak (1. melléklet). Ezeket a szavakat szókapcsolatokon keresztül választottuk ki. A legelső szavunk a gépjármüjavítás, majd ezek különböző szinonimái. A következőkben konkrétabb problémákra kerestünk, mint például a kuplungjavitás vagy a klímaszerelés. Az utolsó 10 szavunk ritkábban előforduló problémákra keresett szolgáltatást, mint a féltengely gumiharang csere, porlasztó csúcs csere. A 100 szóból összesen 46 keresésre jelent meg Google Ads által létrehozott hirdetés. 
A további 54 keresésben az organikus hirdetések között nem szerepelt fizetett hirdetés. Az a 46 szó, amelyre fizetett hirdetések jelentek meg, összesen 88 weboldalt eredményezett, ami 180 -szor jelent meg. Megvizsgáltuk, hogy mely szavak eredmé- nyezték a legtöbb SEM keresést (1. táblázat). Ez a 11 szó összesen 78 hirdetett linket eredményezett a 180-ból. Tehát a szavak $24 \%$-a vezetett a megjelent linkek 43\%-ához.

1. táblázat: A legtöbb keresést eredményező szavak Table 1. Words that resulted the highest number of search

\begin{tabular}{|l|l|c|}
\hline & \multicolumn{1}{|c|}{ Keresett szó } & Hirdetések száma \\
\hline 1. & márka független & 7 \\
\hline 2. & időszakos szerviz & 7 \\
\hline 3. & futómú szerviz & 7 \\
\hline 4. & szélvédő javítás & 7 \\
\hline 5. & szélvédő csere & 7 \\
\hline 6. & autómentés & 6 \\
\hline 7. & gépjármüszerelés & 6 \\
\hline 8. & autógumi javítás & 6 \\
\hline 9. & motorszerviz & 6 \\
\hline 10. & felni centírozás & 6 \\
\hline 11. & ülésfütés javítás & \\
\hline
\end{tabular}

Forrás: saját szerkesztés

A keresések alapján azon weboldalakat elemeztük, amelyek fizetett hirdetéseket alkalmaztak. A kvalitatív tartalomelemzés (Rohrer 2014) során az alábbi szempontrendszert határoztuk meg:

- a link nyitóoldala (Hova vezet? Milyen jellegü tartalom látható?),

- a hirdetés tárgya,

- reszponzívitás,

- $\quad$ sütik használata,

- design (színvilág, tipográfia, vizuális elemek),

- tartalom (információ, aktualitás),

- user experience (UX) (oldal kezelhetősége, átláthatósága és menük száma) (2. melléklet).

\section{EREDMÉNYEK RESULTS}

Google Ads hirdetések az autószereléssel kapcsolatos szavak keresése során - Google Ads during the search of words connected to car repairing sector

A weboldalaknál 46,6\%-ban a föoldalra, 42\%ban valamilyen aloldalra, 11,4\%-ban pedig landing page típusú weboldalakra irányították a hirdetést. A landing page aránya a legalacsonyabb, holott ez a forma lenne a legkedvezőbb a hirdetések hatékonysága szempontjából, hiszen egyetlen ajánlatot kínál letisztult, koncentrált formában (blog.webshark. hu).

Megvizsgáltuk, hogy a nyitóoldalon lévő információk mire irányulnak. A legtöbb, összesen 63 a szolgáltatások népszerüsítésére, 8 a vállalat bemutatására, illetve 10 a márkaszervízekre hirdetett. Az akcióra irányuló linkek száma 5 darab. Szereléssel, javítással kapcsolatos keresésekre, hírekre 1, 
és az álláshirdetésekre is csupán csak egy weboldal tünt fel.

A mobil eszközök egyre gyakoribb használata miatt, az eszközfüggő reszponzív weboldal elengedhetetlen (Nagy 2014). Ugyanis azok, akik rendelkeznek okostelefonnal 91\%-uk használja internetezésre, ezáltal az asztali gépek és laptopok használata visszaszorult az elmúlt években (NMHH 2018). Azok a weboldalak, amelyek nem mobilra optimalizáltak, elveszítik az érdeklődőket, ugyanis nem nyújtja számukra a megfelelő felhasználói élményt. Összesen 15 olyan weboldal fordult elö, amely nem volt mobilra optimalizálva, és 4 olyan, amely csak részben, mivel némely helyen az optimalizálás után egybecsúszott a felső navigációs rész, vagy a képek nem voltak megfelelően méretezve. A többi 69 honlap teljes mértékben megfelelt a reszponzívitásnak.

A sütik összességében hasznos és mára megkerülhetetlen elemei az internetes böngészésnek. Olyan fájlok, amelyek a felhasználó merevlemezén vagy böngészőjében tárolnak adatokat. Ezek célja, hogy a felhasználó testreszabott felületen szörfölhessen, a weboldal kezelöje javítani tudja a felhasználói élményt, valamint a remarketing. Megfelelö müködés esetén a felhasználók a róluk gyüjtött információk alapján személyre szabott, számukra releváns hirdetésekkel találkozhatnak (Gulyás 2006). A w3techs.com oldal statisztikái alapján 2021 áprilisában a létező weboldalak 45,6\%-a használ sütiket, ezen oldalak $80,7 \%$-a használ nem biztonsági sütiket is. A vizsgált 88 weboldalból 51\% használ a honlapon elhelyezett sütiket, $49 \%$ pedig nem, ami megfelelő aránynak mondható.

\section{Design, tartalom és $U X$ szempontok Aspects of design, content and $U X$}

A vizuális megjelenésnél több szempontot is vizsgáltunk, ilyen a színvilág, a betű mérete és típusa, valamint a vizuális elemek. Megnéztük, hogy azonos színvilágot használnak-e a honlap minden részénél, illetve hogy azok a színek menynyire állnak összhangban egymással. Egy egységes színvilág növeli a felhasználói élményt, illetve segít az adott vállalat imázsát beazonosítani, megjegyezni. Egy kivételével minden honlap egységes színvilággal rendelkezett. Ennél az egy honlapnál azt tapasztaltuk, hogy a hátteret egy kép alkotta, amely miatt nehézzé vált szöveg olvasása, illetve a menükhöz tartozó színek nem illettek a háttérkép színvilágához.

A honlapokon használt betük típusait és méreteit vizsgáltuk meg olvashatósági szempontból.
A betük típusával egyik weboldalnál sem volt probléma, viszont 8 weboldalnál gondot okozott a túl kicsi betüméret (12p-nál kisebb). A további 80 honlapon megfelelő méretü betüket találtunk.

A vizuális elemeknél a legújabb webgrafikai trendeknek való megfelelést vizsgáltuk, mint például a weboldal stílusához hasonló képek használata, videók beszúrása, menü kialakítása. Mikor megnyitunk egy weboldalt, pár másodperc alatt eldöntjük, hogy elhagyjuk, vagy maradunk. A honlapok 21\%-a nem megfelelő vizuális elemekkel rendelkezett: kevés kép, nem volt szimmetria, vagy a kialakítása a régebbi trendek alapján történt. Összességében a weboldalak 79\%-a minden szempontnak megfelelt, azaz egységes volt a színvilága, a vizuális elemeket jól alkalmazta, a betütípusa, és a mérete is olvasható volt.

Napjainkban, a tartalommarketing egyik legnépszerübb és leghasznosabb online marketing eszköz, tehát a kevés tartalom, információk hiánya nagy hátrány a weboldalak számára. Hasznos információk nyújtásával, például blog bejegyzéssel, problémák megoldására szolgáló szakértői cikkekkel, vagy a pozitív vásárlói véleményekkel, nagyban befolyásolják a vásárlási döntéseket (Gulyásné Kerekes 2014). Megvizsgáltuk mely honlapok használják ki a tartalommarketing előnyeit. A honlapok 77\%-a látja el elegendő információval a felhasználókat a szolgáltatásról, a vállalatról, illetve egyéb a vállalathoz kapcsolódó hírekről, aktualitásokról. A többi 23\%-nak érdemes lenne felzárkózni az információk megosztásával, mivel így bizalmat építenek ki a falhasználóval. Az organikus elérést is javítva, így a megfelelö SEO alkalmazásával magasabb helyet érhetnek el a keresési listában, mindezt térítésmentesen.

A weboldalak alján található évszám alapján megnéztük a létrejöttük évét. A honlapok több mint a felénél nem tüntették fel az adatokat, összesen 47 darabnál. 30\%-a a hirdetett linkeknek friss weboldal, 9\% 1-2 éves, 7\%-uk pedig ennél régebbi.

A $U X$-en belül megfigyeltük a weboldal kezelhetőségét, az átláthatóságát és a menük számát. A weboldal kezelhetőségénél azt vizsgáltuk, hogy a funkciók (menük, linkek, letöltés, videók), hogyan viselkednek. A 88 weboldalból mindegyiket könnyen tudtuk kezelni, a funkciók is megfelelően müködtek. Az átláthatóságnál, arra voltunk kíváncsiak, hogy első megtekintésre mennyire áttekinthető az oldal (Pl.: Az útvonal egyszerüsége a nyitó oldalról a szolgáltatásokra, vagy az elérhetőségekre.). Egyik weboldalnál sem tapasztaltunk nehézséget. A menük számát is megnéztük, hiszen egy tartalomgazdag weboldalt sokkal átláthatóbbá tesz a jó menüstruktúra. Összesen 6 weboldal volt 
landing page típusú, viszont abból 4 alkalmaz menüt. 7 oldal 1-2 menüt használ, 11 3-5 menüt, 19 6-8 menüt, a legtöbb weboldal (45) nyolcnál is többet. A weboldalak elemzési szempontjait, a kvalitatív és a kvantitatív tartalomelemzés eredményeit a 2. melléklet foglalja össze.

\section{A honlap létrejötte és a vizuális design közötti összefüggés \\ The connection between the establis- hment of the websites and the visual elements}

A honlap létrejötte és a vizuális design közötti összefüggést kereszttáblaelemzés segítségével vizsgáltuk. A friss honlapok szinte kivétel nélkül mind (96,2\%), az 1-2 éven belül kialakított weblapok 62,5\%-a, viszont az ennél régebbiek csupán $57,1 \%$-a tartalmaz sok, modern vizuális elemet (2. táblázat). A változók közötti kapcsolat erössége gyenge (Cramer féle $\mathrm{V}=0,3$ ). Az újonnan készülö honlapok jól követik a vizuális trendeket, viszont a régebbieket nem feltétlenül frissítik e mentén. Emögött a tulajdonosi szándék hiányát, vagy a technológiai tudásbeli hiányosságokat sejtjük.

2. táblázat: A weboldal létrejötte és a vizuális elemek közötti kapcsolat

Table 2. The connection between the establishment of the websites and the visual elements

\begin{tabular}{|l|c|c|c|c|c|}
\hline & nincs adat & 1 éven belüli & $\begin{array}{c}1-2 \text { éven belül } \\
\text { alakult }\end{array}$ & régebbi & Összesen \\
\hline $\begin{array}{l}\text { sok, modern } \\
\text { vizuális } \\
\text { elem }\end{array}$ & $\begin{array}{c}36 \\
76,6 \%\end{array}$ & $\begin{array}{c}25 \\
96,2 \%\end{array}$ & $\begin{array}{c}5 \\
62,5 \%\end{array}$ & $\begin{array}{c}4 \\
57,1 \%\end{array}$ & $\begin{array}{c}70 \\
79,5 \%\end{array}$ \\
\hline $\begin{array}{l}\text { kevés, nincs } \\
\text { vizuális } \\
\text { elem }\end{array}$ & 11 & 1 & 3 & 3 & 18 \\
\hline Összesen & $23,4 \%$ & $3,8 \%$ & $37,5 \%$ & $42,9 \%$ & $20,5 \%$ \\
\hline
\end{tabular}

Forrás: saját kutatás, Megjegyzés: $\chi^{2}=8,24 ; d f=3, p=0,04$; Cramer féle V=0,30

\section{AZ OLDALAK INFORMÁCIÓ- TARTALMA ÉS A HIRDETETT SZAVAK SZÁMA KÖZÖTTI ÖSZ- SZEFÜGGÉS \\ THE CONNECTION BETWEEN THE INFORMATION CONTENT AND THE NUMBER OF ADVER- TISED WORDS}

A következő lépésben vizsgáltuk a hirdetett szavak száma és a weboldalak információtartalma közötti összefüggést varianciaelemzés segítségével. Figyelembe vettük a szóráshomogenitás feltételét. Nincs szignifikáns különbség a hirdetett szavak számában az információ nagysága alapján. Azonban a kutatásból kiderült, hogy ha sok információt tartalmaz egy weboldal, akkor a vállalat több hirdetett szót alkalmaz (átlagosan 2-3 szót, minimum 1, maximum 13 szót), mint az olyan cégek, amelyeknek kevés információt (átlagosan 1-2 hirdetett szót, minimum 1, maximum 6) tartalmaz a honlapjuk. 


\section{A weboldal nyitó oldalának típusa és a hirdetés tárgya közötti összefüggés The connection between the home page and the subject of the advertising}

A hirdetett link nyitóoldala és a hirdetés tárgya közötti összefüggést kereszttábla elemzés segítségével vizsgáltuk. A $\chi^{2}$ statisztika értelmében nincs statisztikailag szignifikáns összefüggés a változók között. A főoldalak esetében az alábbi hirdetésekkel találkoztunk: szolgáltatás $(68,3 \%)$, márkaszervizek $(22,0 \%)$, vállalat bemutatása $(2,4 \%)$, akció (4,9\%), szereléssel, javítással kapcsolatos hírek $(2,4 \%)$. Az aloldalak $73 \%$-a szolgáltatást, $16,2 \%$-a vállalatot, $8,1 \%$-a akciókat és $2,7 \%$-a álláshirdetés népszerüsítését mutatta. A landing page-ek $80 \%$-a a szolgáltatást, $10 \%$-a a márkaszervízt, $10 \%$-a pedig a vállalatot hirdette.

\section{KÖVETKEZTETÉSEK JAVASLATOK CONCLUSION, SUGGESTION}

Az online hirdetések elkészítésének hatékonyságát leginkább a keresőmotoroknak való megfelelés határozza meg. A kutatás során megtalált 88 weboldal kis része az alapsokaságnak, vagyis az autószerelő szektor vállalkozásai jobban is kihasználhatnák az online hirdetésekben rejlő lehetőségeket. A jól megtervezett, átgondolt, információtartalomban és külalakban megfelelő színvonalú honlap versenyelőnyt jelenthet. A webdesign rendkívül fontos a felhasználók számára, hiszen ez dönti el, hogyan tekintenek rá és milyennek ítélik meg a céget. Az általunk vizsgált vállalatoknak is érdemes figyelemmel kísérni az aktuális trendeket és e mentén folyamatosan frissíteni tartalmaikat, kiemelt figyelemmel a vizuális elemek számára és sokszínűségére (sötét, merész színek, színkombinációk, aszimmetrikus elrendezés, fotó és grafika kevert használata, félkövér betütípus, 3D grafikai elemek, videók).

Összességében megállapíthatjuk, hogy a vizsgált szempontok - a link nyitóoldala, a hirdetés tárgya, reszponzívitás, sütik használata, design, tartalom, UX - szerint jól szerepeltek a szektor vállalkozásai. Ezen túl két fő javaslattal élünk: (1) Használjanak gyakrabban landing page-eket, ezzel javítva a kiemelt információk hatékonyabb közvetítését. (2) Logikusan felépített menürendszerekkel támogassák a látogatóikat a honlap böngészése során.
Számos vállalat már felfedezte a tartalommarketingben rejlő lehetőségeket. Minél több információval van feltöltve egy weboldal, annál szélesebb témakörben tudnak hirdetni a vállalatok, mivel a Google algoritmusa a releváns tartalmakat is figyelembe veszi. A tartalmak szempontjából a weboldalon található információ mennyisége és minősége egyaránt fontos. Bár szignifikáns kapcsolatot nem találtunk a hirdetett szavak száma és az információtartalom között, illetve a weboldal nyitó oldalának típusa és a hirdetés tárgya között, azt gondoljuk, hogy továbbra is a tartalommarketing erősítésében rejlik a hatékony online hirdetés kulcsa. A Google azokat a weboldalakat fogja megbízhatónak tartani, amelyek másik megbízható oldalakról is hivatkozást kapnak. Ezeket a hivatkozásokat a színes és jó tartalmak tudják bevonzani. Érdemes a weboldal célját már a kialakításnál meghatározni, mivel a felhasználó az organikus keresésénél sok esetben először a főoldalt nyitja meg.

A kutatás korlátai között szeretnénk megemlíteni, hogy a tartalomelemzés során azonosított design, tartalom és UX szempontok egy részének megítélése kutatói szubjektivitás alapján történt. A következtetések során kevésbé tudtunk iparág-specifikus szakirodalmi háttérre támaszkodni csupán KKV-marketing és online marketing témakörökhöz kapcsolódó forrásokra.

A kutatás jövőbeli kiterjesztése két szempontból is érdekes lehet. Egyik oldalról a módszertan valamelyik peremfeltételének változása (időintervallum, keresés helyszíne, gyakorisága) során kapott eredmények összevetése. Ennek mértéke és jelentősége - a módszer későbbi online reklámok vizsgálatánál történő alkalmazása során - fontos lehet az időtállóság miatt. Másfelől a weboldalak mellett megjelenő közösségi portálok is az online megjelenés széles tárházát adják. Ezek keresőoptimalizálása és hirdetési gyakorlata is fontos lehet, mert egyre jobban terjednek. 


\section{HIVATKOZÁSOK REFERENCES}

Adami, E. (2018), Styling the self online: semiotic technologization in weblog publishing. Social Semiotics, 28 (5). pp. 601-622. DOI: $.1080 / 10350330.2018 .1504713$

Aswani, R., Kumar, A., Vigneswara, K. P., Yogesh I., Dwivedi, K. (2018), ,Search engine marketing is not all gold: Insights from Twitter and SEO Clerks", International Journal of Information Management, 38(1), 107-116. DOI: 10.1016/j.ijinfomgt.2017.07.005

Bányai, E. (2016), „Vállalatok a közösségi médiában”, in: Fehér, A., Kiss, V. Á., Soós, M., Szakály, Z. (szerk.), Hitelesség és Értékorientáció a Marketingben, Debreceni Egyetem Gazdaságtudományi Kar: Debrecen. 75-84

Bányai, E., Novák, P. (2016), Online üzletek és marketing, Budapest: Akadémiai Kiadó, 188-200.

Barry C., Charleton D. (2009), „In Search of Search Engine Marketing Strategy Amongst SME's in Ireland", in: Filipe J., Obaidat M.S. (eds.), e-Business and Telecommunications. ICETE 2008, Communications in Computer and Information Science, Berlin: Springer, 48(1) 113124. DOI: $10.1007 / 978-3-642-05197-5 \_8$

Bartha, Cs., Márku, A. (2016), „Kreatív nyelvhasználat: a Kárpátaljai magyarok digitális kommunikációjának néhány példája". in: Hires-László, K. (szerk.), Nyelvhasználat, kétnyelvűség - Tanulmányok a Hodinka Antal Nyelvészeti Kutatóközpont kutatásaiból II. II. Rákóczi Ferenc Kárpátaljai Magyar Főiskola, 61-76

Békési, G. (2011), „Webszolgáltatások a KKV-k életében", in: Gazdaság és Szociális Demokrácia - XXI. század - Tudományos Közlemények 2011/25, Általános Vállalkozási Főiskola, Budapest. 215-222

Buvár, Á. (2018), „\#Reklám, \#hirdetés, \#fizetett tartalom: A reklámfelismerés szerepe a reklámmal kapcsolatos attitüdök aktiválásában szponzorált tartalmak esetén", Marketing \& Menedzsment 52(3-4), 33-44

Carson, D. J. (2001), ,The evolution of marketing in small firms", European Journal of Marketing, 19(5), 7-16

Cermak R. (2020) "Culturally sensitive website elements and features: A cross-national comparison of websites from selected countries", Acta Informatica Pragensia, 9(2), 132-153, DOI: 10.18267/J.AIP.137

Chavez J., Shah N.A., Ruoss S., Cuomo R. E., Ward S.R., Mackey T.K. (2021) "Online marketing practices of regenerative medicine clinics in US-Mexico border region: a web surveillance study", Stem Cell Research \& Therapy, 12(1),
189 DOI:10.1186/s13287-021-02254-4

Csordás T., Markos-Kujbus É. (2018), „Netnográfia - a pozitív és negatív online szájreklám tartalmi tulajdonságai", Replika, 106-107(1-2), 185198. DOI: $10.32564 / 106-107.11$

Csordás, T., Gáti. M. (2014), „The new (marketing) role of firms as media content providers-the case of SME's strategic social media presence", Vezetéstudomány - Budapest Management Review, 45(2), 22-32

Dieguez T., Ly N.T., Ferreira L.P., da Silva F.J.G. (2021), Digital Customer Network Strategy Influences on Hotel Business, Lecture Notes in Mechanical Engineering, 420-431. DOI: 10.1007/978-3-030-78170-5_36

Eszes, I. (2011), Digitális gazdaság, Az e-kereskedelem marketinges szemmel, Budapest: Nemzeti Tankönyvkiadó

Fehér, K. (2019), „Új média és digitális marketing: szinergia-modellek és ajánlások a két szakterület közelítéséhez", Marketing \& Menedzsment, 53(1), 5-15

Gáti, M. Gy. (2015), Kis-és középvállalatok marketingtevékenységének befolyásoló tényezöi - Különös tekintettel az online marketingtevékenységekre, Doktori értekezés, Budapest: Budapesti Corvinus Egyetem

Gáti, M., Csordás, T. (2013), „KKV-k tartalomés marketingkommunikációja a közösségi médiában", in Király, É. (szek.), Kiterjesztett marketing, Budapesti Gazdasági Főiskola, Budapest, 335-348

Gulyás, G. Gy. (2006), „Anonim-e az anonim böngésző? Technológiák és szolgáltatások elemzése", Alma Mater sorozat az információ-és tudásfolyamatokról, 10(1), 9-30

Gulyásné Kerekes, R. (2014), „Civil szervezetek online kommunikációs lehetőségei”, in.: Piskóti I. (szerk.): Marketingkaleidoszkóp 2014, Innovációvezérelt marketing, Miskolci Egyetem - Gazdaságtudományi Kar, Marketing Intézet, 83-100

Harsányi, D., Máté, Z., Zarándné Vámosi, K. (2021), „A honlapok értékelésének szempontrendszere", Vezetéstudomány - Budapest Management Review, 52(1), 27-41

Holló, E., Marselek, S. (2017), „A KKV-k helyzete, versenyképesség, innováció és foglalkoztatás", in: Tudás és innováció a XXI. század gazdaságában, Válogatás a Gazdaság- és Társadalomtudományi Kar oktatóinak 2016-os tanulmányaiból (Magyar Tudomány Ünnepe 2016). Eger, Eszterházy Károly Egyetem Líceum Kiadó, 167-181.

Kaewmanee, P., Muangprathub, J., Sae-Jie, W. (2021), "Forecasting Tourist Arrivals with Keyword Search using Time Series", 2021 18th International Conference on Electrical 
Engineering/Electronics, Computer, Telecommunications and Information Technology (ECTI-CON), 2021, 171-174, DOI: 10.1109/ ECTI-CON51831.2021.9454824.

Kató, R., Keller, V. (2019), „Webdesign elemzés a húsipari vállalatok körében", in: Reisinger A., Kecskés P., Buics L., Berkes J., Balassa B. (szerk.) „Kulturális gazdaság” Kautz Gyula Emlékkonferencia elektronikus kötete. Széchenyi István Egyetem, Győr, 1-14

Kumar Sharma N., Chen W.-K., Lai K.-K. (2020), "Challenges and Prospects for Digital Marketers while Dealing with SMEs: An Interview”, $A C M$ International Conference Proceeding Series, 25 (31) 1 DOI:10.1145/3446569.3446573

Moller, K., Anttila, M. (1987), „Marketing capability- A key succes factor in small business?", Journal of Marketing Management, 3(2), 185203

Nagy, Zs. (2014), „Intelligens Webrendszerek”, Doktori értekezés, Debrecen: Debreceni Egyetem, Informatikai Tudományok Doktori Iskola

Nwankwo, S., Gbadamosi, A. (2020), Entrepreneurship marketing, Principles and Practice of SME Marketing, London \& New York: Routledge - Taylor \& Francis Group

Romano, C., Ratnatunga, J. (1995), „The role of marketing: Its impact on small enterprise research", European Journal of Marketing, 29(7), 9-30

Sasvári, P. (2012), „Az információs rendszerek kisvállalati alkalmazásának vizsgálata”, Vezetéstudomány, 43(1. ksz), 56-65

Schmuck, R. (2019), „Vállalati stratégiák a virtuális térben", Taylor Gazdálkodás- és Szervezéstudományi Folyóirat, 35(1), 73-82

Suarez-Carballo, F, Martin-Sanroman, J-R., Galindo-Rubio, F. (2020), Responsive Graphic Marks in the Digital Strategy of the Corporate Visual Identity, Fonseca, Journal of Communication, 20, 71-90. DOI: 10.14201/fjc2020207190

Veszelszki, Á. (2019), „Az Instagram-képek megygyőzési stratégiái a borkommunikációban", Marketing \& Menedzsment, 53(4), 13-24. DOI:10.15170/MM.2019.53.04.02

Vincze, D. (2019), „Élmények a fiatal fogyasztók közösségi média posztjaiban", Marketing és Menedzsment, 53 EMOK Különszám, 57-68. DOI:10.15170/MM.2019.53.EMOK.06

Zeff, R., Aronson, B. (2000), Reklám az interneten, Budapest: Geopress Zrt Kiadó

Zhao, L. (2004), „Jump higher: analyzing web site rank in Google", Information Technology and Libraries 23(4), 108-118

\section{Online források \\ Online references}

autoszektor.hu (2017): Jövedelmező üzlet az autószerelés, mégis fogynak a piaci szereplők, megjelent: 2017.04.26. https://autoszektor. $\mathrm{hu} / \mathrm{hu} /$ content/jovedelmezo-uzlet-az-autoszereles-megis-fogynak-piaci-szereplok (Utolsó letöltés: 2020.11.18.)

Farell, S. (2017): UX Research Cheat Sheet, 2017.02.12. Nilsen Norman Group, https:// www.nngroup.com/articles/ux-research-cheatsheet/ (Utolsó letöltés: 2020.11.14)

http://blog.webshark.hu/2019/01/07/milyen-a-jolanding-page/ (Utolsó letöltés: 2020.05.09.)

https://ads.google.com/intl/hu_hu/home/how-itworks/ (Utolsó letöltés: 2020.01.15.)

https://chiefmartec.com/blog/ (Utolsó letöltés: 2020.05.09.)

https://thepitch.hu/online-marketing-eszkozok/ (Utolsó letöltés: 2020.07.10.)

https://w3techs.com/technologies/details/ce-cookies (Utolsó letöltés: 2021.04.09.)

https://webshark.hu/gyik/mi-seo-jelentese/\#toc0 (Utolsó letöltés: 2020.05.09.)

https://www.internetworldstats.com/stats.htm (Utolsó letöltés: 2020.10.10.)

https://www.ksh.hu/apps/shop.kiadvany?p_kiadvany_id=1051023 (Utolsó letöltés: 2020.02.27.)

https://www.webma.hu/Online_marketing_oktatoanyagok/AdWords_kampany_kezdoknek/ Mi_is_az_a_Google_AddWords.html (Utolsó letöltés: $20 \overline{20}$.08.12.)

Kemp (2021) Digital 2021 Hungary https://datareportal.com/reports/digital-2021-hungary (Utolsó letöltés: 2021.06.02.)

KSH (2018), https://www.ksh.hu/docs/hun/xftp/ idoszaki/pdf/kkv18.pdf (Utolsó letöltés: 2021.05.24.)

KSH (2020), https://www.ksh.hu/docs/hun/xstadat/ xstadat_eves/i_onk003.html (Utolsó letöltés: 2021.05.28.)

MRSZ (2020) Média- és Kommunikációs torták sajtóközlemény, https://mrsz.hu/cmsfiles/d3/0f/ MRSZ_sajtokozlemeny_2020media-komm. torta_20210414_.pdf (Utolsó letöltés: 2021.06.02.)

Nilsen Norman Group, https:/www.nngroup.com/ articles/which-ux-research-methods/ (Utolsó letöltés: 2020.11.14.)

NMHH (2018), http://nmhh.hu/dokumentum/202180/lakossagi_internethasznalat_2018. pdf (Utolsó letöltés: 2020.01.16.)

Rohrer, C. (2014), When to use which User-Experience research methods. 2014.10.12. (Utolsó letöltés: 2020.12.01.) 
Kurucz Attila, PhD. egyetemi docens kurucz.attila@sze.hu

Pete Dorottya, egyetemi hallgató dorottyapete@gmail.com

Keller Veronika, $\mathrm{PhD}$, egyetemi docens kellerv@sze.hu

Széchenyi István Egyetem, Kautz Gyula Gazdálkodástudományi Kar

\section{Online marketing opportunities and challenges in the motor mechanic service market}

\section{THE AIMS OF THE PAPER}

The most important aim of the paper is to explore the online marketing activity of Hungarian car repairing companies operating in the service sector. Precisely the websites of google searching results of words connected to motor mechanic were analysed based on content, design and user experience (UX). Another aim of the paper was to reveal connections between the establishment of the website and the visual elements, or between the number of advertised words and the information content of the websites or between the type of the home page and the objective of the ad.

\section{METHODOLOGY}

Connected to the maintenance and repair of motors 100 words were collected and websites (88) found due to Google Ads were analysed in a qualitative way considering the following aspects home page, objective of the ad, responsivity, use of cookies, design, content and UX. Then quantitative content analysis was conducted and the results were interpreted. The method of searching (query) was standardized - the searching was fixed locally, timely and by network (the same IP address) - to have a relevant comparison.

\section{MOST IMPORTANT RESULTS AND NOVELTY}

$65 \%$ of the analysed websites meet the requirement of all aspects thus they used unified colours, applied the visual elements in a right way and shared enough amount of content and information. The higher the amount of information on a website, the easier to advertise for more expressions. The algorithm of Google is taking into consideration the relevant contents and this leads to a better quality in case of organic and paid reach.

\section{RECOMMENDATION}

These results are useful for SME's operating in the after sale service sector especially car service workshop industry. The Hungarian SME sector should monitor current online marketing trends and changing customer needs since well-planned and organized, creative website with congruent design elements and with appropriate level of information and a sophisticated search engine marketing activity can mean a competitive advantage of companies.

Keywords: online ads, google ads, motor mechanic service 
MELLÉKLETEK

1. melléklet: A kutatás során használt keresőszavak Appendix 1. Searching words used in the research

\begin{tabular}{|c|c|c|c|}
\hline ablakemelő javítás & fékjavítás & jármüjavító & motor tuning \\
\hline ablaktörlő javítás & féklámpa csere & jármüszerelés & motor tuning mühely \\
\hline autóépítés & féknyereg felújítás & kardánkereszt csere & motorkerékpár javítás \\
\hline autó helyreállítás & fékszerviz & $\begin{array}{l}\text { kipufogó javítás } \\
\text { (nem ugyan az) }\end{array}$ & motorkerékpár szerelő \\
\hline autó helyrehozás & féktárcsa felszabályozás & kipufogó szerelés & motorkerékpár szerviz \\
\hline autó helyreigazitás & felni centírozás & klímajavítás & motorszerviz \\
\hline autójavítás & $\begin{array}{l}\text { féltengely gumiharang } \\
\text { csere }\end{array}$ & klímaszerelés & olajcsere \\
\hline autó karbantartás & futómü beállítás & kocsi javítás & porlasztó csúcs csere \\
\hline autómentés & futómü javítás & kocsi rendbetétel & robogó javítás \\
\hline autó motor & futómű szervíz & kocsi szerelés & robogó szerviz \\
\hline autó mühely & gépjármű helyreállítás & kuplungjavítás & szélvédő csere \\
\hline autó rendbetétel & gépjármü helyreigazitás & kuplungszerelés & szélvédő javítás \\
\hline autórestaurálás & gépjármű kiigazítás & kuplung szerviz & személyautó javítás \\
\hline autógumi javítás & $\begin{array}{l}\text { gépjármű motor } \\
\text { problémák }\end{array}$ & márkafüggetlen & személyautó szervíz \\
\hline autóklíma javítás & gépjárműszerelés & $\begin{array}{l}\text { márkafüggetlen autó- } \\
\text { szervíz }\end{array}$ & $\begin{array}{l}\text { személyautó szolgál- } \\
\text { tatások }\end{array}$ \\
\hline autó rádió kilbeszerelés & gépjármü vizsgáztatás & márkafüggetlen szerviz & $\begin{array}{l}\text { személygépkocsi } \\
\text { javítás }\end{array}$ \\
\hline autórestaurátor & gépjármüjavítás & márkaszerviz & $\begin{array}{l}\text { személygépkocsi } \\
\text { szerelés }\end{array}$ \\
\hline autószerelés & gépkocsijavítás & $\begin{array}{l}\text { minden típusú sze- } \\
\text { mélyautó javítás }\end{array}$ & $\begin{array}{l}\text { szereld magad mühe- } \\
\text { lyek }\end{array}$ \\
\hline autószerelő & gumicsere & motor fékjavítás & szerelő garázs \\
\hline autószerelő műhely & gumiszerelés & motor helyreállítás & szerelőmühely \\
\hline autószerviz & gumiszerviz & motorjavítás & szerviz \\
\hline $\begin{array}{l}\text { autóvillamossági } \\
\text { szerelés }\end{array}$ & gyertya csere & motorkarbantartás & turbó szerviz \\
\hline $\begin{array}{l}\text { autóvillamossági } \\
\text { szervíz }\end{array}$ & gyúijtásrendszer javítás & motorszerelés & ülésfütés javítás \\
\hline ékszíj csere & időszakos szervíz & motorszerelő & vezérlés csere \\
\hline fékbetét szerelés & izzító gyertya csere & motor szervizelés & vezérlésjavítás \\
\hline
\end{tabular}


2. melléklet: A tartalomelemzés eredménye a weboldalak esetében Appendix 2. The results of content analysis in case of websites

\begin{tabular}{|c|c|c|}
\hline Szempontok & Tulajdonságok & Honlapok száma \\
\hline \multirow{3}{*}{ Link nyitóoldala } & Főoldal & $41(46,6 \%)$ \\
\hline & Aloldal & $37(42,0 \%)$ \\
\hline & Landing page & $10(11,4 \%)$ \\
\hline \multirow{6}{*}{ Mire irányul a hirdetés } & Szolgáltatás & $63(71,6 \%)$ \\
\hline & Márka, szervíz & $10(11,4 \%)$ \\
\hline & \begin{tabular}{|l|} 
Vállalat bemutatása \\
\end{tabular} & $8(9,1 \%)$ \\
\hline & Akció & $5(5,7 \%))$ \\
\hline & Szereléssel, javítással kapcsolatos keresés, hír & $1(1,1 \%)$ \\
\hline & Álláshirdetés & $1(1,1 \%)$ \\
\hline \multirow{3}{*}{ Reszponzívitás } & Reszponzív & $69(78,4 \%)$ \\
\hline & Részben reszponzív & $4(4,5 \%)$ \\
\hline & Nem reszponzív & $15(17,1 \%)$ \\
\hline \multirow{2}{*}{ Sütik használata } & Használ & $45(51,1 \%)$ \\
\hline & Nem használ & $43(48,9 \%)$ \\
\hline \multicolumn{3}{|l|}{ Design elemek: } \\
\hline \multirow{2}{*}{ Színvilág } & Egységes színvilág & $87(98,9 \%)$ \\
\hline & Nem egységes színvilág & $1(1,1 \%)$ \\
\hline \multirow{3}{*}{ Tipográfia* } & Olvasható a betü mérete és típusa & $80(90,9 \%)$ \\
\hline & Nehezen olvasható a típusa & $0(0,0 \%)$ \\
\hline & Túl kicsi betüméret (12-esnél kisebb) & $8(9,1 \%)$ \\
\hline \multirow{2}{*}{ Vizuális elemek** } & Sok, modern vizuális elem & $70(79,5 \%)$ \\
\hline & Kevés/nincs vizuális elem & $18(20,5 \%)$ \\
\hline \multicolumn{3}{|l|}{ Tartalom: } \\
\hline \multirow{2}{*}{ Információtartalom $* * *$} & Sok információ & $68(77,3 \%)$ \\
\hline & Kevés információ & $20(22,7 \%)$ \\
\hline \multirow{4}{*}{ Létrejötte } & Nincs adat & $47(53,4 \%)$ \\
\hline & Aktuális (1 éven belüli) & $26(29,5 \%)$ \\
\hline & $1-2$ éves & $8(9,1 \%)$ \\
\hline & Régebbi & $7(8,0 \%)$ \\
\hline \multicolumn{3}{|l|}{ UX: } \\
\hline \multirow{5}{*}{ Menük száma } & 0 (Landing page) & $6(6,8 \%)$ \\
\hline & $1-2$ & $7(8,0 \%)$ \\
\hline & $3-5$ & $11(12,5 \%)$ \\
\hline & $6-8$ & $19(21,6 \%)$ \\
\hline & $8+$ & $45(51,1 \%)$ \\
\hline
\end{tabular}

Forrás: saját szerkesztés, $n=88$ weboldal

Megjegyzés:

* túl kicsi betüméret: 12-es betüméretnél kisebb

** sok modern vizuális elem: megfelel a legújabb webgrafikai trendeknek, a weboldal stílusához igazodó képeket, grafikai elemeket használ, videós tartalmak használata

** kevés, nincs vizuális elem: kevés kép (3-nál kevesebb), nem volt szimmetria, vagy a kialakítása a régebbi trendek alapján történt, nincs videós tartalom

*** sok információ: elegendő információ a cégről, szolgáltatásokról, termékekről, minden információ megtalálható

*** kevés információ: nincs elegendő információ a cégről, szolgáltatásokról, termékekről, nincs feltüntetve minden információ, vagyis fel kell venni a kapcsolatot a céggel, hogy választ kapjunk a kérdésünkre 